\author{
KAROLINA ADAMCZYK \\ ORCID: 0000-0001-6465-4175 \\ Uniwersytet Wrocławski \\ 301063@uwr.edu.pl \\ SEBASTIAN BIAEY \\ ORCID: 0000-0001-7911-0365 \\ Uniwersytet Wrocławski \\ 302209@uwr.edu.pl
}

\title{
Sprawozdanie z konferencji „Wpływ pandemii COVID-19 na działalność administracji publicznej" (Wrocław, 9 kwietnia 2021 roku)
}

W roku akademickim 2020/2021 na Wydziale Prawa, Administracji i Ekonomii Uniwersytetu Wrocławskiego powstało Koło Naukowe Samorządu Terytorialnego im. Tadeusza Bigo, którego opiekunami są dr hab. Jerzy Korczak, prof. UWr, oraz dr Justyna Mielczarek-Mikołajów. Grupa studentów swoją działalność rozpoczęła od zorganizowania ogólnopolskiej konferencji naukowej „Wpływ pandemii COVID-19 na działalność administracji publicznej”, która odbyła się 9 kwietnia 2021 roku. Na tematykę wydarzenia wpływ miała obecna sytuacja w kraju i na świecie. Pandemia SARS-CoV-2 oddziałuje na każdy aspekt życia ludzi. Znalazło to przełożenie także na działalność administracji publicznej, która musiała się zdecydować na pracę zdalną oraz na ograniczenie kontaktu z petentami. Każda płaszczyzna usług publicznych została zobligowana do wypracowania nowego systemu działania. W marcu 2021 roku minął rok od wybuchu epidemii w Polsce, dlatego też studenci uznali, że to czas na przedstawienie obserwacji związanych z wprowadzeniem alternatywnych rozwiązań w funkcjonowaniu administracji publicznej.

Wydarzenie zostało otwarte przez dr hab. Bartłomieja Krzana, prof. UWr prodziekana do spraw badań naukowych i współpracy międzynarodowej Wydzia- 
łu Prawa, Administracji i Ekonomii Uniwersytetu Wrocławskiego, który stwierdził, że program konferencji jest bardzo wartościowy. Wyraził także nadzieję na możliwość zorganizowania w przyszłości w murach Uniwersytetu Wrocławskiego podobnych konferencji. Słowo wstępne wygłosił również opiekun Koła Naukowego Samorządu Terytorialnego im. Tadeusza Bigo — dr hab. Jerzy Korczak, prof. UWr. Profesor podkreślał, że inicjatorem utworzenia Koła jest jego Prezes - Sebastian Biały. Odniósł się również do wyboru patrona. Przyznał, że ustanowienie nim profesora Tadeusza Bigi było dla niego zaskoczeniem. Wspomniał, że Koło Naukowe Samorządu Terytorialnego dopiero rozpoczęło swoją działalność i że w krótkim czasie udało mu się zorganizować konferencję, która ma bogaty program oraz charakter międzynarodowy. Ten ostatni zawdzięczano obecności prelegenta z Ukrainy - Ihora Moroza. Część oficjalna zakończyła się wystąpieniem Prezesa Koła - Sebastiana Białego, który serdecznie wszystkich powitał i zachęcił do dyskusji.

Konferencja cieszyła się dużym zainteresowaniem wśród studentów, doktorantów oraz przedstawicieli nauki. Wielość zgłoszeń umożliwiła podzielenie wystąpień na cztery bloki tematyczne. Wyróżnione zostały panele: administracyjny, samorządowy, proceduralny oraz finansowy. Każdy z nich zaczynał się słowem wstępnym moderatora i kończył dyskusją oraz pytaniami do prelegentów.

Rozważania konferencyjne w panelu administracyjnym zapoczątkował dr Paweł Bednarski z Państwowej Szkoły Wyższej Zawodowej w Raciborzu, który przedstawił referat Wplyw pandemii COVID-19 na cyfryzację administracji publicznej. Analizie poddał działanie mechanizmu społecznej izolacji. Zwrócił uwagę, że środki bezpieczeństwa zdominowały funkcjonowanie organów administracji. Ich zastosowanie ograniczyło zakres świadczonych usług przez podmioty publiczne oraz prywatne. Wskazywał, że wiele instytucji zostało zmuszonych do ograniczenia albo zawieszenia działalności. Część z nich zdecydowała się na pracę w trybie zdalnym. Doprowadziło to do rozwoju cyfryzacji i stosowania najnowszych rozwiązań technologicznych. Podkreślał, że potrzeby obywateli zaspokojono dzięki istnieniu platformy ePUAP oraz rezygnacji z zasady czynnego udziału stron. Większość spraw urzędniczych petenci mogli załatwiać za pomocą wspomnianej platformy oraz innych środków komunikacji elektronicznej. Doktor Bednarski swoje rozważania zakończył próbą oceny wprowadzonych rozwiązań do usług administracji publicznej.

Jako drugie wystąpiły mgr Kamila Brylak-Hudyma oraz mgr Krystyna Rogala. Doktorantki z Uniwersytetu Wrocławskiego przygotowały wystąpienie pod tytutem COVID-19 a odformalizowanie komunikacji z administracja — zaproszenie do dyskusji, w którym podkreśliły, że lockdown stał się impulsem do wykorzystywania dostępnych rozwiązań technologicznych. Wymiana informacji między organem administracji publicznej a obywatelem stała się możliwa dzięki środkom komunikacji elektronicznej. W swoim referacie zaznaczyły, że takie odformalizowania procedury administracyjnej spowodowało powstanie szeregu zagrożeń. Związane one 
były między innymi z weryfikacją tożsamości interesanta, a także ochroną danych osobowych. Panie Magister porównały również sposób załatwiania spraw drogą mailową przed pandemią oraz w jej trakcie. Swoje obserwacje poparły danymi pochodzącymi z badań empirycznych organów administracji publicznej.

Problematykę cy fryzacji usług publicznych poddał analizie także student Uniwersytetu Jagiellońskiego w Krakowie - Oskar Kański, który uznał, że rola e-administracji znacznie wzrosła przez wybuch epidemii. Wpłynęło to na rozwój wykorzystywanych w komunikacji elektronicznej innowacyjnych technologii. Prelegent postawił także kilka pytań - jakie rozwiązania stosowane są w państwach zachodnich? Czy jest możliwa ich recepcja bądź twórcze rozwijanie w Polsce? Starając się na nie odpowiedzieć, stwierdził, że e-administracja stała się wyzwaniem dla Polski, ale także motywacją do skorzystania z szansy bycia nowoczesnym państwem.

W 2020 roku polski rząd stanął przed wyzwaniem zorganizowania wyborów prezydenckich. Pojawiło się wiele pomysłów, w jaki sposób można je przeprowadzić. Czy byłoby możliwe elektroniczne głosowanie, które wydaje się najbezpieczniejsze w czasach epidemii? Na to pytanie starał się odpowiedź student Uniwersytetu Mikołaja Kopernika w Toruniu i Prezes Studenckiego Koła Naukowego Prawa Wyborczego - „Elektor”, który przygotował referat Gtosowanie elektroniczne (e-voting) jako skuteczne narzędzie e-administracji gwarantujace czynny udziat $w$ wyborach $w$ dobie pandemii COVID-19. Michał Kołbuc uważał, że e-voting to alternatywna forma głosowania, która zapewnia powszechny charakteru wyborów, a tym samym umożliwia zrealizowanie konstytucyjnego obowiązku.

Doktorantka Uniwersytetu Wrocławskiego, Karina Pilarz, poddała rozważaniom nowe regulacje prawne, które pojawiły się odnośnie do inwestycji budowlanych w okresie pandemii SARS-CoV-2. Uznała, że znacznie ułatwiają one i skracają procedury administracyjno-budowlane. Jako przykład podała pominięcie obowiązku respektowania postanowień niektórych aktów normatywnych. Podkreśliła jednak, że te rozwiązania były kontrowersyjne, gdyż inwestorzy wykorzystywali przepisy w sposób sprzeczny z celem ich wprowadzenia.

Kwestię dostępu do informacji publicznej podjął Daniel Matwiejczyk — student Uniwersytetu w Białymstoku. Tę tematykę przedstawił na podstawie ustawy o dostępie do informacji publicznej. Skupił się przede wszystkim na szybkości, działaniu oraz relacji między urzędnikiem a obywatelem, ale także na sposobie realizacji zadań, które bezpośrednio wynikały z ustawy. Ten ostatni aspekt odniósł do statystyk osób chorujących na COVID-19. Do przedstawienia swoich obserwacji i wyników wykorzystał dane statystyczne organizacji pozarządowych oraz literaturę przedmiotu.

Jako ostatnia w panelu administracyjnym występowała Paulina Sowińska studentka Uniwersytetu Marii Curie-Skłodowskiej w Lublinie, która przygotowała wystąpienie dotyczące nieodpłatnej pomocy prawnej w czasach pandemii. Prelegentka wskazała, że poruszyła tę tematykę ze względu na powstałe zmiany 
w ustawach o nieodpłatnej pomocy prawnej, nieodpłatnym poradnictwie obywatelskim oraz o edukacji prawnej, którą przygotowało Ministerstwo Sprawiedliwości. Za cel swojego wystąpienia przyjęła wykazanie tego, jak wybuch epidemii wpłynął na realizację zadań związanych z zapewnieniem przez państwo dostępu do nieodpłatnej pomocy prawnej. Wyodrębniła pozytywne i negatywne skutki pojawienia się nowych regulacji we wspomnianych ustawach. Dopełnieniem wygłoszonego referatu było powołanie się na opinie obywateli, których bezpośrednio dotknęły nowelizacje aktów prawnych.

Panel drugi - samorządowy - otworzyło wystąpienie Michała Masełki. Student Uniwersytetu Wrocławskiego i członek Koła Naukowego Samorządu Terytorialnego zaprezentował swoje obserwacje na temat funkcjonowania administracji publicznej w dobie epidemii na przykładzie Urzędu Miasta Lubań. Debiutant scharakteryzował szereg problemów, które dotknęły działalności instytucji. Wśród nich wyróżnił takie kwestie, jak utrudniona komunikacja z interesantami, przestrzeganie restrykcji sanitarnych przez urzędników niedysponujących indywidualnymi gabinetami. Problematyczne stało się także doręczania decyzji podatkowych. Zdecydowano więc, że osobno zatrudnione zostaną osoby, które będą dostarczać dokumenty. Nie chciano narażać urzędników na niebezpieczeństwo, gdyż spowodowałoby to kolejne problemy. Michał Masełko wspomniał również, że urzędy dostosowały się do ogólnych przepisów. Swoje rozważania oparł na informacjach od Naczelnika Urzędu Miasta Lubań.

Anna Stefaniak — studentka Uniwersytetu Marii Curie-Skłodowskiej w Lublinie - przygotowała referat Wpływ pandemii COVID-19 na dostepp do ustug stużby zdrowia. Prelegentka zauważyła, że z największymi trudnościami musiała zmierzyć się służba zdrowia. Szpitale, przychodnie i kliniki przekształcono w ośrodki walczące z koronawirusem. W związku z tym działalność wobec pacjentów cierpiących na choroby przewlekłe czy ulegających wypadkom znacznie ograniczono. Studentka przedstawiła także szereg problemów formalnych, z którymi muszą zmierzyć się potrzebujący pomocy medycznej.

Sebastian Biały zapoczątkował w panelu samorządowym cykl wystąpień poruszających tematykę wykonywania zadań publicznych z zakresu oświaty. Wskazał dwa projekty rządowe, które dotyczyły dofinansowania jednostek oświatowych na zakup sprzętów dla uczniów i nauczycieli. Zwrócił też uwagę na problemy, z którymi spotykała się dyrekcja szkół oraz uczniowie. Na podstawie danych z Centralnej Komisji Egzaminacyjnej i Okręgowej Komisji Egzaminacyjnej we Wrocławiu omówił zmiany w wynikach egzaminów ósmoklasisty oraz matur. Jednocześnie stwierdził, że kompleksowy opis konsekwencji zdalnego nauczania będzie można sformułować po tegorocznych egzaminach. To one okażą się wykładnikiem tego, jak zdalne nauczanie oddziałuje na edukację.

Studentka Uniwersytetu Przyrodniczo-Humanistycznego w Siedlcach — Klaudia Gozdek - przeanalizowała kwestię e-learningu. Określiła pozytywne oraz negatywne skutki nauczania na odległość. Za zalety uznała oszczędność czasu 
i środków finansowych, natomiast za wady — problemy techniczne związane ze słabym połączeniem internetowym, trudności w skupieniu się i przyswojeniu wiedzy. Swoje obserwacje i sformułowane wnioski oparła na badaniach statystycznych. Porównała wyniki sprzed pandemii z tymi w trakcie jej trwania.

Jakub Choryński — student Uniwersytetu im. Adama Mickiewicza w Poznaniu — dokonał próby oceny nauki zdalnej i nakreślenia dalszych perspektyw z nią związanych. W celu sformułowania wniosku wykorzystał badania statystyczne, odnoszące się do edukacji w czasie pandemii w Polsce. Przedstawił również opinie rodziców, uczniów oraz nauczycieli na zaistniałą sytuację.

Daniel Jakubowski zajął się tematem Zapomoga $w$ dobie pandemii. Referat przygotował na podstawie ustawy Prawo o szkolnictwie wyższym i nauce. Nowelizacja przepisu, który reguluje przyznawanie tego świadczenia - według przedstawiciela Uniwersytetu Warszawskiego - generuje wątpliwości praktyczne. Za problematyczne uznał on wyłączenie stosowania regulacji Kodeksu postępowania administracyjnego podczas przyznawania świadczenia, ponieważ ogranicza to prawa studenta $\mathrm{w}$ zakresie starania się o otrzymanie zapomogi. Kolejną trudnością okazało się wyłączenie stosowania art. 92 ust. 2 tejże ustawy, ponieważ nie posiadał on charakteru wyłącznego.

Natalia Karlic to studentka Uniwersytetu Wrocławskiego, członkini Koła Naukowego Samorządu Terytorialnego, która tę konferencję wybrała na swój debiut. Zaprezentowała referat $W p t y w$ pandemii COVID-19 na działalność miejskich ośrodków pomocy społecznej. Przedstawiła ogólne zmiany w funkcjonowanie tychże instytucji. W prezentacji odniosła się także do opinii Dyrektor Miejskiego Ośrodka Pomocy Społecznej w Kamiennej Górze wskazującej na różnorodne trudności, z którymi zmagają się organy administracji publicznej od początku epidemii.

Przedstawiciel Uniwersytetu Warszawskiego - Piotr Markowicz - poruszył kwestię kampanii Europejskiego Tygodnia Zrównoważonego Transportu w 2020 roku, ponieważ uznał, że sektor transportu zbiorowego został znacznie ograniczony przez koronawirusa. Na początku swojego wystąpienia opisał główne cele kampanii, wykorzystywane strategie oraz podmioty biorące w niej udział. Następnie odniósł się do wyzwań, z którymi musieli się zmierzyć organizatorzy tego wydarzenia, gdy ogłoszono stan epidemiologiczny.

Ostatnim uczestnikiem panelu samorządowego był Ihor Moroz. Uczestnik Programu Stypendialnego im. Lane'a Kirklanda na Uniwersytecie Wrocławskim nadał konferencji charakter międzynarodowy. Rozważaniom poddał działalność Dolnośląskiego Centrum Filmowego w okresie zagrożenia epidemiologicznego, a tym samym wskazał ograniczenia, które instytucja musiała wprowadzić w swoim funkcjonowaniu.

Panel trzeci — proceduralny — otworzyła dr Maria Jędrzejczyk z Uniwersytetu im. Adama Mickiewicza w Poznaniu, która omówiła wprowadzone rozwiązania w zakresie obradowania organów kolegialnych jednostek samorządu 
terytorialnego. Przedstawicielka nauki wskazała, że obrady oraz inne czynności przeniesiono do sfery wirtualnej, jednakże nie wszystkie rozwiązania zostały zaaprobowane przez organy nadzoru i sądy administracyjne.

Jako drugi występował mgr Adam Bródka, który poddał rozważaniom postępowanie administracyjne. Doktorant Uniwersytetu Wrocławskiego przedstawił swoje obserwacje odnoszące się do trudności prowadzenia spraw administracyjnych. Związane one były z ograniczeniem kontaktów międzyludzkich. Prelegent wykazał, że organy administracji publicznej musiały odstąpić od realizacji zasady czynnego udziału stron w postępowaniu. Komunikacja bezpośrednia stała się niezauważalna nie tylko na linii administracja — petent, ale także na linii pracownik — pracownik. Spowodowało to dodatkowe problemy w zakresie przekazywania sobie potrzebnej dokumentacji.

Mgr Beniamin Rozczyński z Uniwersytetu im. Adama Mickiewicza w Poznaniu swój referat oparł na pytaniu: czy aktualnie istniejące środki procesowe o charakterze upraszczającym, a w szczególności rozwiązania prowadzące do elektronizacji postępowania administracyjnego, są korzystne dla jednostki z punktu widzenia ochrony jej uprawnień? W trakcie wystąpienia starał się udzielić na nie odpowiedzi. Umożliwiło mu to przyjęcie pewnych kryteriów do oceny polskiej procedury administracyjnej.

Mgr Agnieszka Polus analizowała zasadność nakładania administracyjnej kary pieniężnej, które była konsekwencją nieprzestrzegania przepisów tak zwanych rozporządzeń covidowych. Doktorantka Uniwersytetu Mikołaja Kopernika w Toruniu w swoim wystąpieniu zastanawiała się, czy wprowadzone ograniczenia na podstawie rozporządzeń były zgodne z Konstytucją RP. Swoje wątpliwości opierała na analizie wyroku Wojewódzkiego Sądu Administracyjnego w Opolu, który uchylił decyzję w przedmiocie kary pieniężnej za niezastosowanie się do czasowego ograniczenia prowadzenia działalności.

Reprezentant Uniwersytetu Łódzkiego — mgr Marcin Berezowski — opisywał reformy, które wprowadzono w zakresie prowadzenie postępowań sądowych w sprawach cywilnych i karnych. Zasadniczą zmianą było zrezygnowanie z ustnego i bezpośredniego charakteru postępowań. Zauważył także, że wypracowane rozwiązania staną się podstawą do dalszych badań nad funkcjonowaniem systemu prawnego w stanie epidemiologicznym.

Doktorant Uniwersytetu Mikołaja Kopernika w Toruniu — Paweł Kamiński — zakończył panel trzeci referatem o postępowaniu egzekucyjnym. Przedstawił wpływ przepisów Tarcz Antykryzysowych na działalność organów egzekucyjnych. Wskazał, że największemu ograniczeniu uległy egzekucje z nieruchomości.

Wystąpienie doktora Andrzeja Halickiego zapoczątkowało panel finansowy. Reprezentant Stowarzyszenia „Wrażliwy Obywatel” poruszył kwestie odnoszące się do funkcjonowania Krajowej Administracji Skarbowej w rzeczywistości pandemicznej. Postawił pytanie — jaki wpływ na działalność KAS miała pandemia? 
Aby udzielić na nie odpowiedzi, dokonał analizy procesu rekrutacji do Służby Celno-Skarbowej, a także sposobu realizacji zadań kontrolnych.

O nowych uprawnieniach podatkowych rad gmin opowiadała dr Magdalena Krzysztof-Pelka z Uniwersytetu Śląskiego w Katowicach. Prelegentka wskazywała, że rady gminy uzyskały nowe uprawnienia, dzięki którym miały możliwość podejmowania uchwał w sprawie zwolnień z podatku od nieruchomości czy też przedłużania terminów płatności podatku od nieruchomości. Nowe regulacje prawne przybrały charakter ogólny. W związku z tym pojawiły się problemy interpretacyjne, praktyczne, legislacyjne i teoretyczne.

Celem prezentacji Dominiki Tabis — reprezentantki Uniwersytetu Jagiellońskiego — było zilustrowanie sytuacji finansowej samorządów. Studentka pokazała, jak ograniczenia dotyczące wpływów z dochodów z tytułu podatków PIT, CIT, transportu publicznego i wynajmu nieruchomości oddziaływały na wykonywanie zadań przez organy administracji publicznej. Swoje tezy poparła danymi liczbowymi oraz analizą skutków kryzysu finansowego. Dodatkowo odpowiedziała na postawione na początku pytania: jak pandemia wpłynęła na budżety samorządów? W jaki sposób samorządy mogą sobie poradzić z trudną sytuacją?

Martyna Grzegorzak zbadała, jak epidemia SARS-CoV-2 wpłynęła na sposób zarządzania budżetem miast. Studentka Uniwersytetu Marii Curie-Skłodowskiej uwzględniła w analizie miejskie procesy inwestycyjne, które dotyczyły rozwoju transportu zbiorowego oraz przestrzeni publicznej. Wskazywała, że ograniczenia komunikacji miejskiej pozytywnie oddziaływały na prace podejmowane w zakresie kreowania przestrzeni publicznej. Zmniejszone natężenie ruchu przyczyniło się do łatwiejszej modernizacji budynków czy poszerzania chodników. Także zamykanie ulic dla pojazdów mechanicznych nie okazało się tak uciążliwe, jak zakładano.

Ostatnim prelegentem był mgr Jakub Baranowski, którego referat można potraktować jako uzupełnienie poprzedniego wystąpienia. Martyna Grzegorzak zajęła się analizą budżetu miast, natomiast doktorant z Uniwersytetu Szczecińskiego — budżetu obywatelskiego miast na prawach powiatu. Według niego największą trudnością dla organów administracji publicznej stał się kontakt z obywatelami. Wcześniej procesy partycypacyjne charakteryzowały się bezpośrednią interakcją z mieszkańcami danego obszaru. W rzeczywistości pandemicznej wszelkie działania musiały się odbywać za pomocą narzędzi komunikacji zdalnej. Umożliwiło to podtrzymanie zaangażowania obywateli w sprawy miasta. Reprezentant Uniwersytetu Szczecińskiego ocenił zastosowane rozwiązania w procesach partycypacyjnych budżetu obywatelskiego.

Panele administracyjny, samorządowy, proceduralny, finansowy moderowali odpowiednio: Sebastian Biały, mgr Karina Pilarz, dr Justyna Mielczarek-Mikołajów i mgr Mateusz Adamczyk. Każdą część zakończono dyskusją, która była bogata $\mathrm{w}$ pytania, komentarze oraz dopowiedzenia. Studenci, doktoranci oraz przedstawiciele nauki mogli przedstawić swoje obserwacje oraz wnioski na tematy, które zaprezentowali inni prelegenci. 
Konferencję podsumowali opiekunowie Koła Samorządu Terytorialnego im. Tadeusza Bigo — dr hab. Jerzy Korczak, prof. UWr oraz dr Justyna Mielczarek-Mikołajów, którzy podziękowali występującym za przygotowane referaty oraz zaangażowanie i wyrazili nadzieję na kolejne wydarzenia. 